\title{
Joy Parr, Sensing Changes: Technologies, Environments, and the Everyday, 1953-2003 (Vancouver: UBC Press, 2010).
}

By focusing on the way that people adapted to the environmental and technological changes wrought by Canadian megaprojects in the post-World War II period, Joy Parr's book, Sensing Changes: Technologies, Environments, and the Everyday, 19532003, gives voice and validity to stories about displacement, disorientation, and the rupture of familiar patterns of daily living. As the title suggests, Parr plots the transformation of everyday living by focusing on how people physically experienced megaprojects - not only through their senses of sight, sound, hearing, touch, and smell, but also proprioception (sense of movement and balance), kinaesthesia (sense of place and movement), and proxemics (sense of distance). By working with New Media scholar, Jonathan Van der Veen, to create the book's accompanying Mega Project's website, Parr also experiments with communicating these stories in multi-sensory ways, using songs, interview excerpts, photographs, and interactive maps to illustrate changes in the landscape and the impact this had for the people who occupied it before and after the megaprojects were completed.

The book is divided into six case studies. The first explores the case of the North Atlantic Treaty Organization base that was established in 1952 at Gagetown, New Brunswick. The chapter is about how people used the land for pasture and woodlands prior to it being transformed by tank mazes and firing ranges and how their displacement from it transformed their understanding of politics and citizenship. The second case study explores how workers in Canadian nuclear power plants - Chalk River, Bruce, and Point Lepreau - adapted their modes of work and movement to protect themselves from the insensible dangers of radiation. Parr reveals how, under the leadership of the physicist, Lorne McConnell, radiation health and safety policy was unique for its emphasis on educating nuclear workers about radiation hazards and making health and safety their responsibility. Chapter four is about the people of Iroquois, Ontario. Without consulting the villagers, Ontario Hydro moved the town $1.6 \mathrm{~km}$ north in 1958 to make way for the St. Lawrence Seaway project, completely cutting people off from access to the waterway that had been so central to their daily existence and placing the town in a space that was barren of mature trees. Parr highlights that the coincident shifts toward modern consumerism (in the form of shopping plazas) and watching television exacerbated the pace at which the villager's relationship with their community members and the town was altered by the move. Chapter five turns to the effects that the 1962 Columbia River Treaty had on the people living around the Arrow Lakes in British Columbia, focusing on how the radical alteration (and accompanying unpredictability) of the lakes affected their sense of time, "distance, direction, and depth." To accommodate the American need for 
hydro-electric power, the Treaty resulted in the transformation of the lakes into a large reservoir that displaced many of the surrounding residents. Chapter six returns to the site of the Bruce Nuclear Generating Station, exploring how uncertainty surrounding the health and environmental effects of hydrogen sulphide, a by-product of the heavy water production plant that was opened at Bruce Peninsula, affected local farmers and visitors to Inverhuron Provincial Park. Chapter seven is about the E. coli contamination of Walkerton, Ontario's water supply in 2000. Within are stories about how the local townspeople grappled with the reality that their senses of taste were no longer reliable for determining water safety, the pitfalls of fiscal conservatism, how differently Walkerton residents and urban Canadians understood the contamination, and how public utility employees, Stan and Frank Koebel's well-intentioned tinkering with water safety reports failed to account for the ways that population increases, changing agricultural practices, and altered uses of the land made older ways of ensuring water quality ineffective.

The book is unique for Parr's willingness to let her subjects shape the stories told in each chapter. Indeed, as she reveals on the first page of the introduction, what started out as a book about Canadian megaprojects was slowly reframed to focus on the people whose lives and senses of self had been transformed by them. While it would have been good for Parr to include more direct quotations from her many interviews in the body of the book, the separate webpage devoted to each chapter on the Mega Projects website more than makes up for their absence in the text. In particular, it is clear from the interviews showcased on the Iroquois webpage that Parr allows the interviewee's to guide her towards exploring topics of relevance to them.

Since the focus of each chapter is on displacement, change, and the rupture of familiar patterns of daily living in Canadian hinterlands, it would have been a wonderful opportunity to do a comparative analysis of a related case in a Canadian Aboriginal or Inuit community. Such an approach could help build understanding and empathy across racial and ethnic lines in Canada, something that is challenging to nurture in students of history and the broader community of Canadians, in general, for whom knowledge about and interaction with First Nations' People remains minimal.

This final critique is meant more as food for thought and should not dissuade a wide range of academics from using this text and the Megaprojects Website for teaching both undergraduate and graduate students. The New Media component of Sensing Changes is a wonderful illustration of how we can and should engage our students in multi-sensory ways and how we, as historians, must move beyond privileging the written word.

Lisa Rumiel

McMaster University

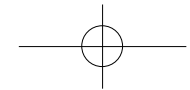

